\title{
Impact of processing conditions and gelling agent on physical and sensorial properties of pecan oil-dulce de leche gummy candies
}

\author{
Impacto das condições de processamento e do agente \\ gelificante nas propriedades físicas e sensoriais das balas \\ mastigáveis de doce de leite com óleo de pecã
}

\author{
Natalia Ranalli ${ }^{1,2 *}$ (D), Luz Adornato ${ }^{3}$, Alicia Noemí Califano ${ }^{1,3}$, Silvina Cecilia Andrés ${ }^{1,3}$ \\ ${ }^{1}$ Centro de Investigación y Desarrollo en Criotecnología de Alimentos (CIDCA), CONICET, CICPBA, Facultad de \\ Ciencias Exactas, Universidad Nacional de La Plata, La Plata, Argentina \\ ${ }^{2}$ Universidad Nacional de La Plata (UNLP), Facultad Ingeniería, Departamento de Ingeniería Química, La Plata - \\ Argentina \\ ${ }^{3}$ Universidad Nacional de La Plata (UNLP), Facultad de Ciencias Exactas, La Plata - Argentina \\ *Corresponding Author: Natalia Ranalli, Universidad Nacional de La Plata (UNLP), Consejo Nacional de \\ Investigaciones Cientificas y Tecnicas (CONICET), Centro de Investigación y Desarrollo en Criotecnología de \\ Alimentos (CIDCA), Facultad de Ciencias Exactas, 47 y 116, 1900, La Plata, Buenos Aires - Argentina, e-mail: \\ nataliaranalli@gmail.com
}

Cite as: Ranalli, N., Adornato, L., Califano, A. N., \& Andrés, S. C. (2020). Impact of processing conditions and gelling agent on physical and sensorial properties of pecan oil-dulce de leche gummy candies. Brazilian Journal of Food Technology, 23, e2019177. https://doi.org/10.1590/1981-6723.17719

\begin{abstract}
For the development of gelatinized dairy products that include emulsified pecan oil as an unsaturated fatty acid source the incorporation of hydrocolloids becomes necessary and their properties must be carefully selected. This work aimed to study gelatinized candies made with $0 \%$ milk fat dulce de leche with pre-emulsified pecan nut oil using combinations of gelatin $(4.67$ to $7 \mathrm{~g} / 100 \mathrm{~g})$ and high methoxyl pectin $(1.33$ to $2 \mathrm{~g} / 100 \mathrm{~g})$ as gelling agents. The effect of different drying methods (vacuum-oven at $35^{\circ} \mathrm{C}$ for $24 \mathrm{~h}$ and freeze-drying) was evaluated. Control samples without drying were also studied. Dehydration conditions significantly $(p<0.05)$ affected $\mathrm{a}_{\mathrm{w}}$ texture (hardness, cohesiveness, adhesiveness, gumminess, springiness, and resilience) and color parameters $\left(\mathrm{L}^{*}, \mathrm{a}^{*}, \mathrm{~b}^{*}\right)$ of products, being higher than the effect of the gelling agent. Formulations were selected based on texture and $a_{w}$ criteria and sensory evaluated by appearance, color, texture, taste, and overall acceptability. Two formulations (one with $7 \%$ gelatin and $1.33 \%$ high methoxyl pectin content, and the other with $2 \%$ high methoxyl pectin and $4.67 \%$ gelatin content), both with low moisture content and vacuum-dried, exhibited good acceptability. These pecan oildulce de leche gummy candies would represent a healthier candy version, low in saturated fatty acids, and source of oleic acid.
\end{abstract}

Keywords: Gummy candies; Gelling agents; Dairy products; Texture; Dulce de leche; Pecan oil.

\section{Resumo}

Para o desenvolvimento de produtos lácteos gelatinizados que incluem óleo de nozes pecã emulsionado, como fonte de ácido graxo insaturado, a incorporação de hidrocoloides se torna necessária, e as propriedades devem ser cuidadosamente especificadas. $O$ objetivo deste trabalho foi estudar balas de goma feitas com doce de leite 
$0 \%$ de gordura de leite e com óleo de noz-pecã pré-emulsionado, utilizando combinações de gelatina (4,67 a $7 \mathrm{~g} / 100 \mathrm{~g})$ e pectina de alto grau de metoxilação $(1,33$ a $2 \mathrm{~g} / 100 \mathrm{~g})$ como agentes gelificantes. O efeito de diferentes métodos de secagem (estufa a vácuo a $35{ }^{\circ} \mathrm{C}$ por $24 \mathrm{~h}$ e liofilização) foi avaliado. Amostras-controle sem secagem também foram estudadas. As condições de desidratação afetaram significativamente $(p<0,05)$ a textura (dureza, coesividade, adesividade, gomosidade, elasticidade e resiliência) e os parâmetros de cor ( $L$ * a *, $b^{*}$ ) dos produtos, sendo superiores ao efeito do agente gelificante. As formulações foram selecionadas com base nos critérios de textura e $a_{w}$ e avaliadas sensorialmente quanto a aparência, cor, textura, sabor e aceitabilidade geral. Duas formulações (uma com 7\% de gelatina e 1,33\% de pectina de alto grau de metoxilação e outra com $4,67 \%$ de gelatina e $2 \%$ de pectina de alto grau de metoxilação), ambas com baixo teor de umidade e secas a vácuo, apresentaram boa aceitabilidade. Essas balas de goma de de doce de leite com óleo de pecã representam uma versão mais saudável, com baixo teor de ácidos graxos saturados e fonte de ácido oleico.

Palavras-chave: Bala de goma; Gelificantes; Produtos lácteos; Textura; Doce de leite; Óleo de nozes.

\section{Introduction}

Children and adults consumed many confectionery products. According to the Spanish association of confectionary products, more than $50 \%$ of adults regularly consume candies and chewing gums (Martínez, 2012). The confectionery industry has a huge growing market for various products such as chocolates, toffees, bakery, and biscuits (Dasgupta et al., 2019), due to the pleasurable effects and wellness they are capable to provide when consumed in moderate quantities.

Nevertheless, there is a continuous consumer demand for healthier confectionery products. Traditional gummy confection consists of high amounts of sucrose and glucose syrup combined with a gelling agent, commonly gelatin, along with acids, flavorings, and colorings (Marfil et al., 2012). Thinking of candies consumption as a nutrition assistant, it implies changes in both their formulation and dietary habits. Instead of removing sweets from the diet they could be modified and added supplementary benefits, turning into a functional product (Tomassone et al., 2012).

Dulce de leche (DL) is a product traditionally obtained by concentration and heating at a normal or reduced pressure of 3\% w/v fat milk with sucrose and vanilla (Penci \& Marín, 2016; Lorenzo et al., 2020). DL has milk proteins with good nutritive value, but saturated fats are controversial. DL formulated with pecan nut oil (Ranalli et al., 2017) has a fatty acid (FA) balance in favor of unsaturated FA (UFA) as well as the absence of cholesterol in the formulation. Pecan nut oil is neutral in flavor and rich in UFA, mainly oleic and linoleic acids (67.55 and $20.67 \mathrm{~g} / 100 \mathrm{~g}$, respectively (Fernandes et al., 2017), contains no trans fats, and also is rich in tocopherols. It is considered heart-healthy due to its effect on diminishing LDLcholesterol (low-density lipoprotein cholesterol) and heart disease risk (Atanasov et al., 2018). Thus, pecan oil-DL incorporation in gummy candies is a great opportunity to improve unsaturated fatty acids consumption by children and adults through the development of new gelatinized dairy products.

To the best of our knowledge, there are not dulce de leche gummy candies in the market or similar products, and the effect of gelling agents or drying methods to obtain them and also, their properties, have hardly been reported.

The texture of gummy candies is achieved by using various gelling agents, such as gelatin, starch, and pectin. Pectin is a naturally-occurring polysaccharide, mainly extracted from citrus peel and apple pomace. Highly methoxylated pectin is used to form gels in acidic media of high sugar content. The texture of pectin-based gums is soft and short but less chewy than gelatin-based gums (Lubbers \& Guichard, 2003). So, the incorporation of pecan oil-DL into gummy candies implies the use of gelling agents to improve its texture.

This work aimed to study the effect of the gelling agent (gelatin and high methoxyl pectin), the initial moisture of the fresh candies, and the processing conditions (two drying methods) on physical and sensorial 
properties of gummy candies obtained from dulce de leche made with $0 \%$ milk fat and pre-emulsified pecan nut oil.

\section{Materials and methods}

\subsection{Materials}

Enough pecan oil-DL for the manufacture of all candy formulations was obtained according to Ranalli et al. (2017) without xanthan gum incorporation.

Briefly, skim milk (maximum 0.5\% w/v fat according to Código Alimentario Argentino (Argentina, 1999), UHT, Sancor, Cooperativas Unidas Ltda., Santa Fe, Argentina) was incubated with lactase $\left(4{ }^{\circ} \mathrm{C}\right.$, 24 h) (125 NLUL-1, Chr. Hansen Holding A/S, Buenos Aires, Argentina).

Afterward, adequate amounts of sucrose (food-grade, Ledesma SAAI, Tucumán, Argentina), anhydrous glucose (analytical-grade, Parafarm, Saporiti, Buenos Aires, Argentina), sodium bicarbonate (analyticalgrade, Anedra, Research AG, Buenos Aires, Argentina), and potassium sorbate (600 mg sorbic acid/kg product, analytical-grade, Anedra, Research AG, Buenos Aires, Argentina) were dissolved in the milk while enough pecan nut oil (NUCANA, Entre Ríos, Argentina) with tocopherols $(1000 \mathrm{mg} / \mathrm{kg}$, TocomixTM70, AOM S.A., Buenos Aires, Argentina, at least $63 \mathrm{~g}$ no- $\alpha$ tocopherols $/ 100 \mathrm{~g}$, mainly d- $\gamma / \mathrm{d}-\beta$ tocopherol (43.8 g/100 g) and d- $\delta$ tocopherol $(19.3 \mathrm{~g} / 100 \mathrm{~g})$ ) was pre-emulsified to reach a level of $\sim 5 \mathrm{~g}$ oil/ $/ 100 \mathrm{~g}$ in the final product. Pecan oil-DL resulted in $24.8 \mathrm{~g}$ moisture $/ 100 \mathrm{~g}$ and $5.4 \mathrm{~g} \mathrm{lipid} / 100 \mathrm{~g}$ with $62.4 \mathrm{~g}$ oleic $\mathrm{acid} / 100 \mathrm{~g}, 25.4 \mathrm{~g}$ linoleic acid/100 g, and $10.6 \mathrm{~g}$ saturated fatty acids/100 g (Ranalli et al., 2017).

As gelling agent food-grade gelatin (250 bloom, PB Leiner, Sauce Viejo, Santa Fe, Argentina) and high methoxyl pectin (CPKelco, Atlanta, Georgia, USA) were used.

\subsection{Preparation of pecan oil-DL gummy gels}

\subsubsection{Experimental design}

Effect of different levels of gelling agents and moisture in the fresh candy mixtures were studied through an experimental design $2^{3} \times 3$ (Table 1), with gelatin, pectin, and moisture as factors; the fourth factor was the dehydration method, which was studied in all formulations in three levels: i) vacuum-oven drying (VD) at $35^{\circ} \mathrm{C}$ during $24 \mathrm{~h}$; ii) freeze-drying (FD) at $-80^{\circ} \mathrm{C}$; and iii) control samples without drying (C).

Formulations of pecan oil-DL gummy candies were named using lowercase letters to indicate the lower factor level ( $\mathrm{p}, \mathrm{g}$, and $\mathrm{m}$, for pectin, gelatin, and moisture, respectively) and capital letters for the higher level (P, G, and M, for pectin, gelatin, and moisture, respectively).

\subsubsection{Formulation and production}

The amount of water that would be added in each formulation was calculated according to the target initial moisture in the fresh candies. For gummy candies manufacture, pectin was dissolved in part of the calculated water $\left(1: 11\right.$ ratio, $\left.90{ }^{\circ} \mathrm{C}, 15 \mathrm{~min}\right)$, gelatin was hydrated in the remaining water (room temperature), and an adequate amount of pecan oil-DL was templated at $90{ }^{\circ} \mathrm{C}$ in a microwave $(50 \%$ potency, $35 \mathrm{~s}$ ) before mixing with the conditioned gelling agents. Once mixed, hot aliquots of $5 \mathrm{~mL}$ were poured into cylindrical silicone molds $(24.5 \mathrm{~mm}$ diameter, $10.6 \mathrm{~mm}$ height), kept at room temperature for $1 \mathrm{~h}$, and then stored at $4{ }^{\circ} \mathrm{C}$ for $24 \mathrm{~h}$. According to the formulation, between thirteen and fifteen fresh candies were obtained. 
Table 1. Different levels of gelling agents (gelatin, pectin) and moisture in the fresh candy mixtures through an experimental design $2^{3} \times 3$; the fourth factor was the drying method.

\begin{tabular}{|c|c|c|c|c|}
\hline Formulation* & Pectin (g/100 g) & Gelatin (g/100 g) & Moisture (g/100 g) & Drying method $* *$ \\
\hline PGm & 2 & 7 & \multirow{2}{*}{50} & \multirow{8}{*}{ VD } \\
\hline pgm & 1.33 & 4.67 & & \\
\hline pGM & 1.33 & 7 & \multirow{2}{*}{60} & \\
\hline $\mathrm{PgM}$ & 2 & 4.67 & & \\
\hline pGm & 1.33 & 7 & \multirow{2}{*}{50} & \\
\hline Pgm & 2 & 4.67 & & \\
\hline PGM & 2 & 7 & \multirow{2}{*}{60} & \\
\hline $\mathrm{pgM}$ & 1.33 & 4.67 & & \\
\hline PGm & 2 & 7 & \multirow{2}{*}{50} & \multirow{8}{*}{ FD } \\
\hline pgm & 1.33 & 4.67 & & \\
\hline pGM & 1.33 & 7 & \multirow{2}{*}{60} & \\
\hline $\mathrm{PgM}$ & 2 & 4.67 & & \\
\hline pGm & 1.33 & 7 & \multirow{2}{*}{50} & \\
\hline Pgm & 2 & 4.67 & & \\
\hline PGM & 2 & 7 & \multirow{2}{*}{60} & \\
\hline pgM & 1.33 & 4.67 & & \\
\hline PGm & 2 & 7 & \multirow{2}{*}{50} & \multirow{8}{*}{$\mathrm{C}$} \\
\hline pgm & 1.33 & 4.67 & & \\
\hline pGM & 1.33 & 7 & \multirow{2}{*}{60} & \\
\hline $\mathrm{PgM}$ & 2 & 4.67 & & \\
\hline pGm & 1.33 & 7 & \multirow{2}{*}{50} & \\
\hline Pgm & 2 & 4.67 & & \\
\hline PGM & 2 & 7 & \multirow{2}{*}{60} & \\
\hline $\mathrm{pgM}$ & 1.33 & 4.67 & & \\
\hline
\end{tabular}

*Lowercase letters indicate the low level (pectin, gelatin and moisture, $\mathrm{p}, \mathrm{g}$, and $\mathrm{m}$, respectively) and capital letters high level (pectin, gelatin and moisture, $\mathrm{P}, \mathrm{G}$, and $\mathrm{M}$, respectively). ${ }^{* *} \mathrm{VD}$ : vacuum-oven drying, at $35^{\circ} \mathrm{C}$ during $24 \mathrm{~h}$. FD: freeze-drying at $-80{ }^{\circ} \mathrm{C}$. C: control samples without drying.

\subsubsection{Gels processing}

Two drying methods were evaluated: i) vacuum-oven drying (VD) (DZF-6030A, ICSA, Barcelona, Spain) at $35{ }^{\circ} \mathrm{C}$ during $24 \mathrm{~h}$; ii) freeze-drying (FD) (L-A-B4-C, Rificor, Argentina) at $-80{ }^{\circ} \mathrm{C}$. Control samples without drying were also included in the study.

When obtained, products were stored in Ziploc ${ }^{\circledR}$ pouches (C. S. Johnson\&Sons de Argentina S.A.I.C., Buenos Aires) at $4{ }^{\circ} \mathrm{C}$ until analysis.

Additional pecan oil-DL gummy candies were stored in the same bags at room temperature for microbial growth observation (Vilela et al., 2016). 


\subsection{Products characterization}

Water activity $\left(\mathrm{a}_{\mathrm{w}}\right)$ of pecan oil-DL gummy candies was determined in duplicate using AquaLab Series equipment (Decagon Devices, Inc., Pullman, WA, USA) at $25^{\circ} \mathrm{C}$.

The color was measured at room temperature $\left(20^{\circ} \mathrm{C}\right)$ using a Chroma Meter CR-400 colorimeter (Minolta Co., Ramsey, Nueva Jersey, USA) and Commission Internationale de l'éclairage L*a*b* parameters were determined. Colorimeter was calibrated using a white tile $\left(L^{*}=98.45, a^{*}=-0.10\right.$, $\mathrm{b}^{*}=-0.13$; Minolta calibration plate), $8 \mathrm{~mm}$ aperture, illuminant D65 at a standard observation of $2^{\circ}$. Averages of three samples were considered for color data analysis.

Texture Profile Analysis (TPA) was performed on candies at room temperature $\left(20^{\circ} \mathrm{C}\right)$ (Bourne, 1978; Brennan \& Bourne, 1994). Candies (24.5 mm diameter and $10.6 \mathrm{~mm}$ high) were compressed twice to $30 \%$ of their original height between flat plates using a TAXT2i Texture Analyzer (Stable Micro Systems, Godalming, UK) interfaced with a computer, using the software supplied by Texture Technologies Corp. In these experiments, the head was operated at $0.5 \mathrm{~mm} / \mathrm{s}$.

Firmness (peak force of first compression cycle, N), cohesiveness (ratio of positive areas of the second cycle to the area of the first cycle, $\mathrm{J} / \mathrm{J}$, dimensionless), adhesiveness (negative force area of the first byte represented the work necessary to pull the compressing plunger away from the sample, J), gumminess (hardness $\times$ cohesiveness, $\mathrm{N}$ ), springiness (a distance of the detected height of the product on the second compression divided by the original compression distance, $\mathrm{mm} / \mathrm{mm}$, dimensionless), and resilience (the area during the withdrawal of the first compression divided by the area of the first compression, $\mathrm{J} / \mathrm{J}$, dimensionless) were determined ( $\mathrm{n}=12 /($ formulation trial)).

\subsection{Sensorial evaluation}

Four selected pecan oil-DL gummy candy formulations were tested by fifty-five non-trained panelists (25-56 yr. aged). Samples were served in plastic trays in a randomized and balanced manner. Tap water was provided for palate cleansing between samples. Acceptance testing was conducted using a 9-point hedonic scale $(9=$ like extremely, $1=$ extremely dislike) to assess the following attributes: appearance, color, texture, taste, and overall acceptance.

\subsection{Statistical analysis}

Analyses of variance were conducted separately on the dependent variables analyzed. For simultaneous pairwise comparisons, the least significant difference (LSD) test was chosen. Differences in means and Ftests were considered significant when $p<0.05$. All statistical procedures were computed using SYSTAT software (SYSTAT, Inc., Evanston, IL, USA).

\section{Results and discussion}

\subsection{Pecan oil-DL candies characterization}

Through analysis of $a_{w}$ results, the main effect of the drying method was observed; also, initial moisture and gelatin content were significant $(p<0.05)$. Figure 1 shows $a_{w}$ mean values. Starting from $a_{w}$ values higher than 0.93 for control-candies, freeze-dried candies reached low $a_{w}$ values like 0.734 for PgM-FD formulation, while for vacuum-dried products, the lowest $\mathrm{a}_{\mathrm{w}}$ value found was 0.895 for Pgm-VD ones. 


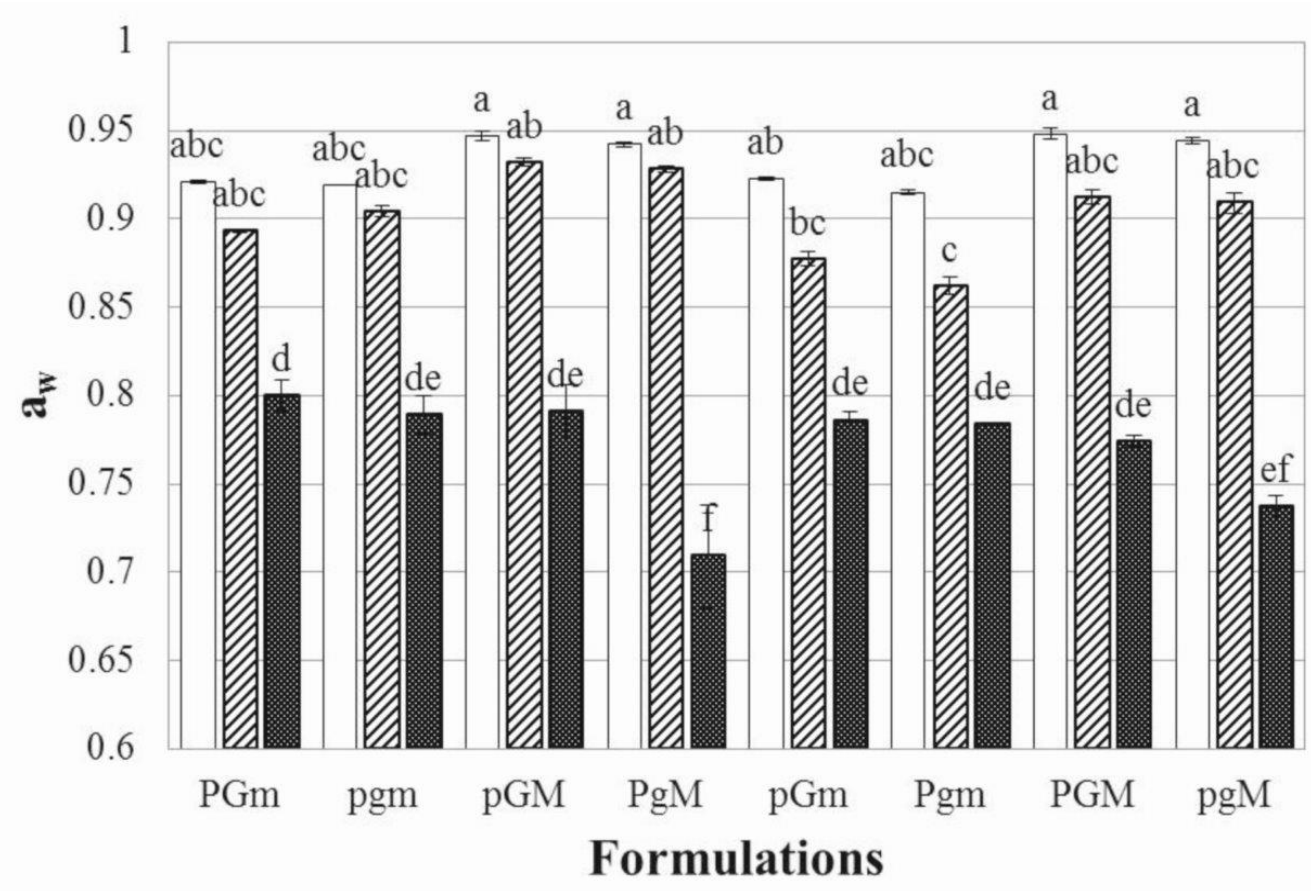

Figure 1. Water activity $\left(a_{w}\right)$ mean values corresponding to different pecan oil-dulce de leche gummy candy formulations (lowercase letters indicate low level (pectin, gelatin and moisture, $\mathrm{p}, \mathrm{g}$, and $\mathrm{m}$, respectively, and capital letters high level (pectin, gelatin and moisture, $\mathrm{P}, \mathrm{G}$, and $\mathrm{M}$, respectively) obtained with diverse drying conditions: vacuum-oven drying $(\mathscr{V})$, freeze-drying ( $)$, control candies without drying $(\square)$. Error bars indicate SEM.

Even though there are no other equivalent products to compare, freeze-dried PgM and pgM formulations showed $a_{w}$ values similar to commercial fruit-based jellies available in the market (average 0.71, Monroy et al., 2017).

When sugars are used as the main hurdle for food preservation, the final $\mathrm{a}_{\mathrm{w}}$ value is usually less than 0.85 , as in most jellies, jams, and candied fruits, or below 0.70 , as in confectionery products. Bacteria cannot grow below $\mathrm{a}_{\mathrm{w}}$ of 0.85 , whereas yeasts and molds growth are slowed down around $\mathrm{a}_{\mathrm{w}}$ of 0.7 and no growth occurs below 0.6 (Labuza et al., 1972). In these shelf-stable candies, $a_{w}$ values of 0.85 or below prevent the growth and production of toxins from all pathogenic bacteria, including $S$. aureus and C. botulinum (Pittia \& Antonello, 2016). However, a high reduction in $\mathrm{a}_{\mathrm{w}}$ could result in a too much harder product, so it would be necessary to evaluate its texture and other physic properties and also consumer's acceptance.

According to results, water activities of some pecan oil-DL candies formulations were in the so-called intermediate products range, 0.80 to 0.85 , or higher. These products would not be self-preserved; however, potassium sorbate added in pecan oil-DL used in their formulations could avoid microbiological problems. Visual observation showed that there was no microbial growth for 3 months for all formulations. Microbial stability studies would be appropriate to assure an adequate shelf life for these products.

Figure 2 shows pecan oil-DL candies color parameters. In agreement with Gaze et al. (2015), positive values of $a^{*}$ and $b^{*}$ indicated a tendency to red-yellow products with a predominance of $b^{*}$ in all samples, due to browning by Maillard and caramelization reactions (Golon \& Kuhnert, 2012; Pathare et al., 2013). Drying method moistly affected color parameters, resulting in lower L* for both VD and FD products, lower $\mathrm{a}^{*}$ and much lower $\mathrm{b}^{*}$ values for FD products concerning controls. 

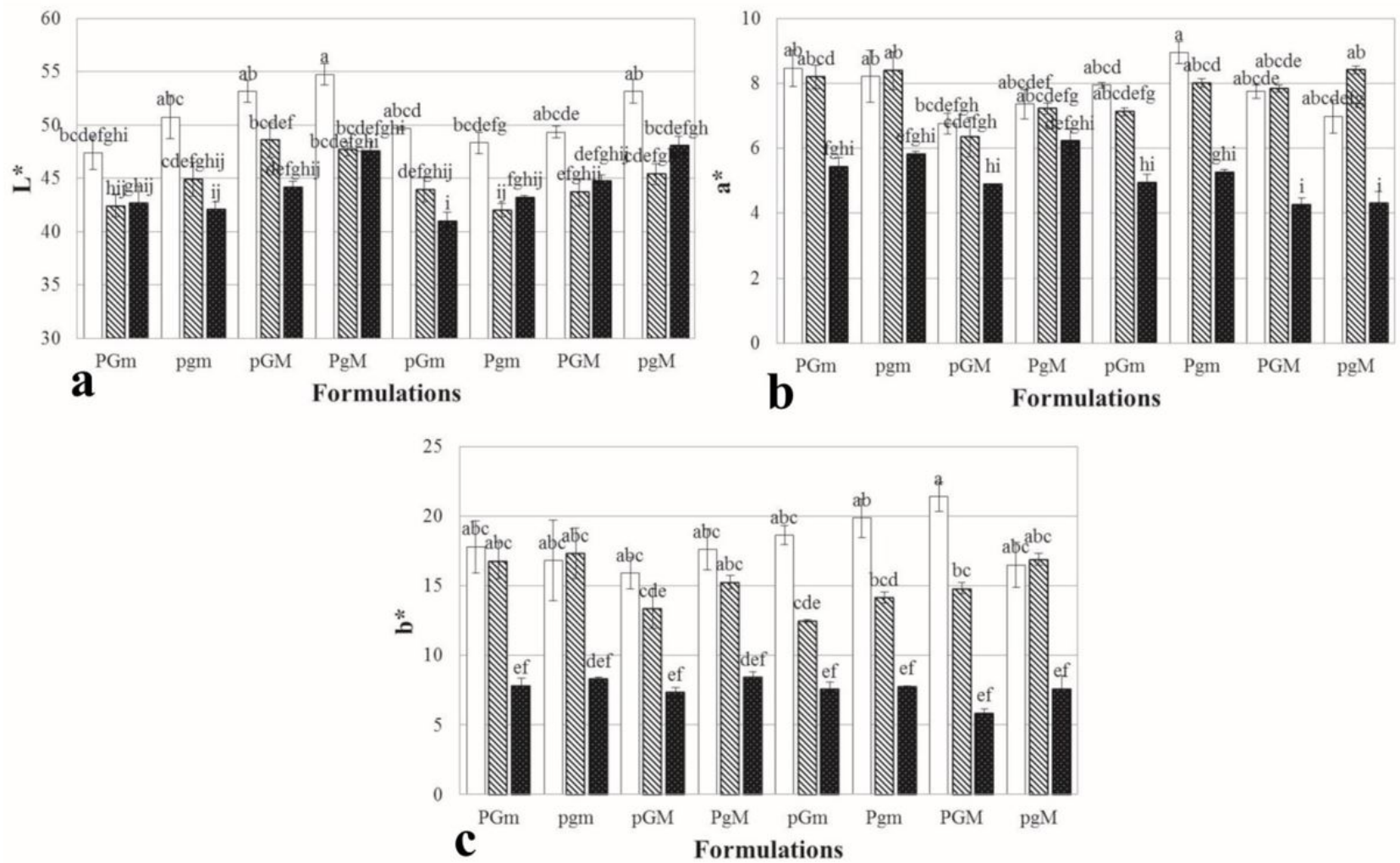

Figure 2. Color parameters a) L*, b) a*, and c) b*, obtained for different pecan oil-dulce de leche gummy candy formulations (lowercase letters indicate low level (pectin, gelatin and moisture, p, g, and m, respectively, and capital letters high level (pectin, gelatin and moisture, P, G, and M, respectively) and drying conditions: vacuum-oven drying $(\mathscr{V})$, freeze-drying ( ) control candies without drying $(\square)$. Error bars indicate SEM.

The product texture is a consequence of its components and their interactions and arrangements in both macroscopic and microscopic levels (Ibáñez et al., 1998). All analyzed TPA parameters were significantly affected by one or more evaluated factors, as can be seen in Table 2. Firmness and gumminess were significantly affected by gelling agents, initial moisture, and drying method, and also by their interactions. As expected, softer products were obtained from higher moisture mixtures, with less gelatin and pectin levels, both for vacuum or freezing drying.

Cohesiveness and springiness parameters were significantly influenced by the drying method $(p<0.05)$, being the effect lower for the last one. The smaller cohesiveness values were obtained for almost all FD candies (Table 2).

Additionally, a mathematical model that relates control pecan oil-DL candies (C) firmness with their $\mathrm{a}_{\mathrm{w}}$ values and gelatin content $\left(\mathrm{x}_{\mathrm{g}}\right)$ was found (Figure 3, Equation 1).

Firmness $(\mathrm{N})=-178.2+3.1 * \mathrm{x}_{\mathrm{g}}(\mathrm{g} / 100 \mathrm{~g})+581.2 * \mathrm{a}_{\mathrm{w}}-432.0 * \mathrm{a}_{\mathrm{w}}^{2}$

According to the model, higher gelatin level $(\mathrm{g} / 100 \mathrm{~g})$ and lower $\mathrm{a}_{\mathrm{w}}$ produced firmer candies.

Taken into account the main fatty acids in the pecan oil-DL (62.4 g oleic acid/100 g, $25.4 \mathrm{~g}$ linoleic acid/100 g, and $10.6 \mathrm{~g}$ saturated fatty acids/100 g, Ranalli et al., 2017) turned into candies and their moisture contents, the products would contain less than $0.5 \mathrm{~g}$ saturated fatty acids $/ 100 \mathrm{~g}$ and more than $2 \mathrm{~g}$ oleic acid/100 g, which could be considered as "low in saturated fatty acids" (less than $1.5 \mathrm{~g}$ saturated fatty acids/100 g) and "sources of oleic acid" (more than $2 \mathrm{~g}$ oleic acid/100 g), respectively, according to the Nutritional Complimentary Information (Argentina, 2012). Also, they would contain more than $0.8 \mathrm{~g}$ linoleic acid/100 g, which would help to improve unsaturated fatty acid consumption. 
Impact of processing conditions and gelling agent on physical and sensorial properties of pecan oil-dulce de leche gummy candies Ranalli, N. et al.

Table 2. Texture parameters of pecan oil-dulce de leche gummy candies with different gelling agents and drying methods.

\begin{tabular}{|c|c|c|c|c|c|c|c|}
\hline Formulation* & $\begin{array}{c}\text { Drying } \\
\text { method** }\end{array}$ & $\begin{array}{c}\text { Firmness } \\
\text { (N) }\end{array}$ & $\begin{array}{c}\text { Gumminess } \\
\text { (N) }\end{array}$ & Springiness & Cohesiveness & $\begin{array}{c}\text { Adhesiveness } \\
\text { (J) }\end{array}$ & Resilience \\
\hline \multirow{3}{*}{ PGm } & $\mathrm{C}$ & $29.32^{\mathrm{c}}$ & $18.44^{\mathrm{c}}$ & $0.980^{\mathrm{ab}}$ & $0.629^{\text {cdefgh }}$ & $-0.52^{\mathrm{abcd}}$ & $0.642^{\mathrm{ab}}$ \\
\hline & VD & $10.59^{\mathrm{f}}$ & $6.89^{\text {efg }}$ & $0.958^{\mathrm{ab}}$ & $0.651^{\text {abcd }}$ & $-0.50^{\mathrm{abcd}}$ & $0.548^{\text {cdef }}$ \\
\hline & FD & $36.10^{\mathrm{b}}$ & $22.52^{\mathrm{ab}}$ & $0.905^{\mathrm{ab}}$ & $0.623^{\text {defgh }}$ & $-0.36^{\mathrm{abc}}$ & $0.485^{\mathrm{ghi}}$ \\
\hline \multirow{3}{*}{ pgm } & $\mathrm{C}$ & $5.38^{\text {ghi }}$ & $3.40^{\mathrm{hi}}$ & $0.966^{\mathrm{ab}}$ & $0.633^{\text {cdefg }}$ & $-0.58^{\mathrm{abcd}}$ & $0.597^{\mathrm{bc}}$ \\
\hline & VD & $5.60^{\text {ghi }}$ & $3.65^{\text {ghi }}$ & $0.9130^{\mathrm{ab}}$ & $0.654^{\mathrm{abc}}$ & $-0.67^{\mathrm{abcd}}$ & $0.495^{\text {fghi }}$ \\
\hline & FD & $22.36^{\mathrm{d}}$ & $13.60^{\mathrm{d}}$ & $0.912^{\mathrm{ab}}$ & $0.608^{\mathrm{gh}}$ & $-0.91^{\mathrm{cd}}$ & $0.451^{\mathrm{ij}}$ \\
\hline \multirow{3}{*}{ pGM } & $\mathrm{C}$ & $5.38^{\text {ghi }}$ & $3.43^{\mathrm{hi}}$ & $0.952^{\mathrm{ab}}$ & $0.637^{\text {cdefg }}$ & $-0.34^{\mathrm{abc}}$ & $0.675^{\mathrm{a}}$ \\
\hline & VD & $3.45^{\mathrm{i}}$ & $2.24^{\mathrm{i}}$ & $1.114^{\mathrm{a}}$ & $0.651^{\mathrm{abcd}}$ & $-0.14^{\mathrm{ab}}$ & $0.579^{\mathrm{c}}$ \\
\hline & FD & $28.21^{\mathrm{c}}$ & $17.83^{\mathrm{c}}$ & $0.904^{\mathrm{ab}}$ & $0.632^{\text {cdefg }}$ & $-0.31^{a b c}$ & $0.454^{\mathrm{ij}}$ \\
\hline \multirow{3}{*}{$\mathrm{PgM}$} & $\mathrm{C}$ & $3.68^{\mathrm{i}}$ & $2.36^{\mathrm{i}}$ & $0.954^{\mathrm{ab}}$ & $0.642^{\text {bcdef }}$ & $-1.02^{\mathrm{d}}$ & $0.644^{\mathrm{ab}}$ \\
\hline & VD & $3.28^{\mathrm{i}}$ & $2.18^{\mathrm{i}}$ & $1.001^{\mathrm{ab}}$ & $0.665^{\mathrm{ab}}$ & $-0.29^{a b c}$ & $0.520^{\text {defg }}$ \\
\hline & FD & $28.65^{\mathrm{c}}$ & $17.53^{\mathrm{c}}$ & $0.876^{\mathrm{b}}$ & $0.612^{\mathrm{gh}}$ & $-0.19^{\mathrm{ab}}$ & $0.393^{k}$ \\
\hline \multirow{3}{*}{ pGm } & $\mathrm{C}$ & $10.94^{\mathrm{f}}$ & $7.01^{\mathrm{ef}}$ & $0.955^{\mathrm{ab}}$ & $0.641^{\text {bcde }}$ & $-0.59^{\mathrm{abcd}}$ & $0.635^{\mathrm{ab}}$ \\
\hline & VD & $15.33^{\mathrm{e}}$ & $9.91^{\mathrm{e}}$ & $0.956^{\mathrm{ab}}$ & $0.647^{\text {abcdef }}$ & $-0.41^{\text {abcd }}$ & $0.573^{\mathrm{cd}}$ \\
\hline & FD & $41.54^{\mathrm{a}}$ & $25.82^{\mathrm{a}}$ & $0.920^{\mathrm{ab}}$ & $0.622^{\text {efgh }}$ & $-0.39^{\mathrm{abcd}}$ & $0.510^{\text {efgh }}$ \\
\hline \multirow{3}{*}{ Pgm } & $\mathrm{C}$ & $7.65^{\mathrm{fgh}}$ & $4.96^{\text {fghi }}$ & $0.978^{\mathrm{ab}}$ & $0.648^{\text {abcdef }}$ & $-0.84^{\text {cd }}$ & $0.546^{\text {cdef }}$ \\
\hline & VD & $8.93^{\mathrm{fg}}$ & $5.75^{\mathrm{fgh}}$ & $0.913^{\mathrm{ab}}$ & $0.643^{\text {abcdef }}$ & $-0.31^{\mathrm{abc}}$ & $0.465 \mathrm{hi}$ \\
\hline & FD & $36.88^{b}$ & $22.26^{\mathrm{ab}}$ & $0.908^{\mathrm{ab}}$ & $0.603^{\mathrm{h}}$ & $-0.42^{\mathrm{abcd}}$ & $0.453^{\mathrm{ij}}$ \\
\hline \multirow{3}{*}{ PGM } & $\mathrm{C}$ & $7.34^{\mathrm{fgh}}$ & $4.77^{\text {fghi }}$ & $0.975^{\mathrm{ab}}$ & $0.65^{\text {abcde }}$ & $-0.40^{\mathrm{abcd}}$ & $0.685^{\mathrm{a}}$ \\
\hline & VD & $10.68^{\mathrm{f}}$ & $7.13^{\mathrm{ef}}$ & $1.101^{\mathrm{a}}$ & $0.671^{\mathrm{a}}$ & $-0.09^{\mathrm{a}}$ & $0.555^{\text {cde }}$ \\
\hline & FD & $37.03^{b}$ & $23.48^{\mathrm{a}}$ & $0.914^{\mathrm{ab}}$ & $0.635^{\text {cdefg }}$ & $-0.16^{\mathrm{ab}}$ & $0.469^{\text {ghi }}$ \\
\hline \multirow{3}{*}{ pgM } & $\mathrm{C}$ & $4.08^{\mathrm{hi}}$ & $2.66^{\mathrm{hi}}$ & $0.962^{\mathrm{ab}}$ & $0.652^{\mathrm{abcd}}$ & $-0.74^{\text {bcd }}$ & $0.637^{\mathrm{ab}}$ \\
\hline & VD & $5.33^{\text {ghi }}$ & $3.47^{\mathrm{hi}}$ & $1.073^{\mathrm{ab}}$ & $0.651^{\mathrm{abcd}}$ & $-0.20^{\mathrm{ab}}$ & $0.569^{\mathrm{cd}}$ \\
\hline & FD & $31.55^{\mathrm{c}}$ & $19.58^{\mathrm{bc}}$ & $0.886^{\mathrm{b}}$ & $0.621^{\mathrm{fgh}}$ & $-0.36^{\mathrm{abc}}$ & $0.404^{\mathrm{jk}}$ \\
\hline
\end{tabular}

*Lowercase letters indicate the low level (pectin, gelatin and moisture, $\mathrm{p}, \mathrm{g}$, and $\mathrm{m}$, respectively) and capital letters high level (pectin, gelatin and moisture, P, G, and M, respectively). **VD: vacuum-oven drying, at $35^{\circ} \mathrm{C}$ during $24 \mathrm{~h}$. FD: freeze-drying at $-80{ }^{\circ} \mathrm{C}$. C: control samples without drying. Different letters in the same column indicate significant differences $(p<0.05)$.

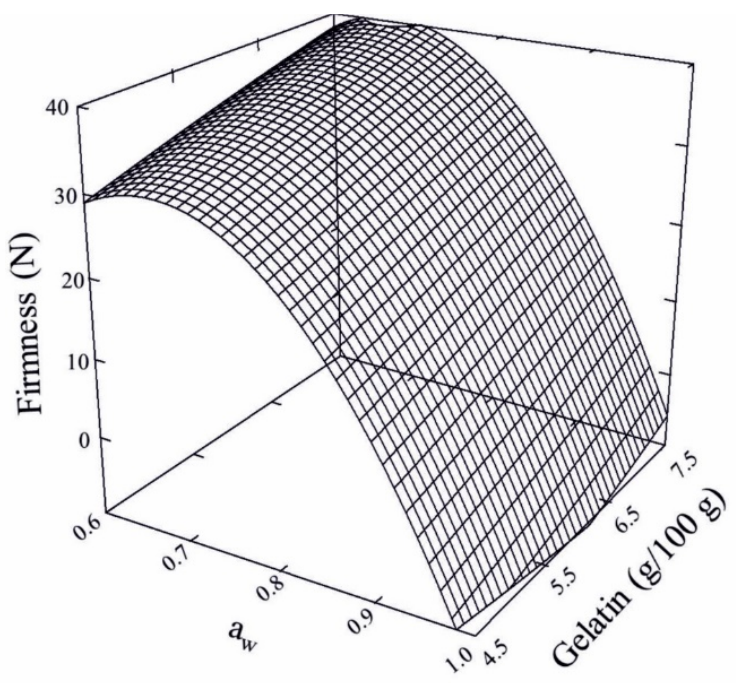

Figure 3. Firmness of control pecan oil-dulce de leche gummy candies as a function of water activity and gelatin content. 


\subsection{Sensorial assay}

For sensory analysis, four pecan oil-DL gummy candies formulations were chosen: two that were vacuum-dried and resulted in the lowest water activities (pGm and Pgm), and two that were freeze-dried and ended in the lowest firmnesses (pgm and pGM).

Table 3 shows the results of the acceptance test. As it can be seen, most of the formulations were accepted by panelist (scored $>5$, like slightly or more (Lim, 2011)), only both freeze-dried products were given scores under 5 for texture. Also, all sensorial characteristics except taste were higher for vacuumdried candies. From the acceptance test, only the drying method was significant on appearance, color, texture, and overall acceptance. However, taste scores were higher for pgm-FD and both vacuum-dried formulations (pGm-VD and Pgm-VD), which may be due to their higher dulce de leche relative content since those corresponded to formulations with lower initial moistures.

Table 3. Sensorial evaluation of pecan oil-dulce de leche gummy candies.

\begin{tabular}{ccccc}
\hline \multirow{2}{*}{ Attribute } & \multicolumn{4}{c}{ Formulation* } \\
\cline { 2 - 5 } & pGm-VD & Pgm-VD & pgm-FD & pGM-FD \\
\hline Appearance & $7.25^{\mathrm{b}}(0.23)$ & $7.18^{\mathrm{b}}(0.25)$ & $5.27^{\mathrm{a}}(0.31)$ & $5.49^{\mathrm{a}}(0.30)$ \\
\hline Color & $7.40^{\mathrm{b}}(0.21)$ & $7.42^{\mathrm{b}}(0.22)$ & $5.95^{\mathrm{a}}(0.30)$ & $5.95^{\mathrm{a}}(0.29)$ \\
\hline Texture & $6.53^{\mathrm{b}}(0.32)$ & $7.07^{\mathrm{b}}(0.29)$ & $4.24^{\mathrm{a}}(0.36)$ & $4.37^{\mathrm{a}}(0.37)$ \\
\hline Taste & $5.78^{\mathrm{ab}}(0.27)$ & $6.56^{\mathrm{a}}(0.25)$ & $6.60^{\mathrm{a}}(0.31)$ & $5.18^{\mathrm{b}}(0.29)$ \\
\hline Overall acceptability & $6.89^{\mathrm{b}}(0.22)$ & $6.89^{\mathrm{b}}(0.23)$ & $5.73^{\mathrm{a}}(0.27)$ & $5.11^{\mathrm{a}}(0.26)$ \\
\hline
\end{tabular}

*Lowercase letters indicate the low level (pectin, gelatin and moisture, $\mathrm{p}, \mathrm{g}$, and $\mathrm{m}$, respectively) and capital letters high level (pectin, gelatin and moisture, $\mathrm{P}, \mathrm{G}$, and $\mathrm{M}$, respectively). FD and $\mathrm{VC}$ indicate freeze-dried and vacuum dried samples, respectively. Liking attributes were scored on a 9-point hedonic scale, where $1=$ dislike extremely and $9=$ like extremely. Different letters in the same row indicate significant differences $(p<0.05)$.

The consumer's preferences for this type of product are largely based on textural characteristics, so obtaining correlations between instrumental and sensorial measures can be extremely useful for quality control and product design in industries. When sensory acceptability was correlated with hardness, a negative correlation ( $\mathrm{R} 2=0.90, p=0.05)$ was found, which indicates that consumers preferred vacuumoven dried products.

\section{Conclusions}

It was possible to make pecan oil-dulce de leche gummy candies and evaluate the effect of processing conditions and gelling agents on the physical and sensorial properties of the products. The drying method had the main effect on $a_{w}$ values and color parameters. Firmness and gumminess were significantly affected by gelling agents, initial moisture, and drying method, and also by their interactions. The smaller cohesiveness values were obtained for almost all freeze-dried candies. From the acceptance test, only the drying method was significant on appearance, color, texture, and overall acceptance. Vacuum-dried products with the lowest $\mathrm{a}_{\mathrm{w}}$ values and freeze-dried candies with the lowest firmnesses were well accepted by the panelists, with a higher preference for vacuum-oven dried products that were less hardness than the freeze-dried ones. Also, all sensorial characteristics except taste were higher for vacuum-dried candies. These pecan oil-dulce de leche gummy candies would represent a healthier version, low in saturated fatty acids, and a source of oleic acid. 


\section{Acknowledgements}

This research was supported by Consejo Nacional de Investigaciones Científicas y Tecnológicas (CONICET, Argentina), Agencia Nacional de Promoción Científica y Tecnológica, and Universidad Nacional de La Plata.

In memory of Dr. Alicia Califano (1951-2019), Lead Scientist (CIDCA-CONICET, Argentina), and a highly respected colleague who will be greatly missed.

\section{References}

Argentina. (1999). Código Alimentario Argentino: Alimentos lácteos (Cap. VIII). Buenos Aires: Ministerio de Salud. Retrieved in 2019, February 15, from https://www.argentina.gob.ar/sites/default/files/capitulo_viii_lacteosactualiz_2019-03.pdf

Argentina. Mercado Común del Sur - MERCOSUR. (2012). Reglamento técnico Mercosur sobre información nutricional complementaria (declaraciones de propiedades nutricionales) (MERCOSUR/GMC/RES no 01/12). Boletín Oficial de la República Argentina, Buenos Aires. Retrieved in 2019, February 15, from http://www.puntofocal.gov.ar/notific_otros_miembros/pry33a1_t.pdf

Atanasov, A. G., Sabharanjak, S. M., Zengin, G., Mollica, A., Szostak, A., Simirgiotis, M., Huminiecki, Ł., Horbanczuk, O. K., Nabavi, S. M., \& Mocan, A. (2018). Pecan nuts: A review of reported bioactivities and health effects. Trends in Food Science \& Technology, 71, 246-257. http://dx.doi.org/10.1016/j.tifs.2017.10.019

Bourne, M. C. (1978). Texture profile analysis. Food Technology, 32, 62-66.

Brennan, J. G., \& Bourne, M. C. (1994). Effect of lubrication on the compression behaviour of cheese and frankfurters. Journal of Texture Studies, 25(2), 139-150. http://dx.doi.org/10.1111/j.1745-4603.1994.tb01322.x

Dasgupta, N., Ranjan, S., \& Gandhi, M. (2019). Nanoemulsions in food: Market demand. Environmental Chemistry Letters, 17(2), 1003-1009. http://dx.doi.org/10.1007/s10311-019-00856-2

Fernandes, G. D., Gómez-Coca, R. B., Pérez-Camino, M. C., Moreda, W., \& Barrera-Arellano, D. (2017). Chemical characterization of major and minor compounds of nut oils: Almond, hazelnut, and pecan nut. Journal of Chemistry, 11, 1-11. http://dx.doi.org/10.1155/2017/2609549

Gaze, L. V., Costa, M. P., Monteiro, M. L. G., Lavorato, J. A. A., Conte Júnior, C. A., Raices, R. S. L., Cruz, A. G., \& Freitas, M. Q. (2015). Dulce de Leche, a typical product of Latin America: Characterisation by physicochemical, optical and instrumental methods. Food Chemistry, 169, 471-477. PMid:25236253. http://dx.doi.org/10.1016/j.foodchem.2014.08.017

Golon, A., \& Kuhnert, N. (2012). Unraveling the chemical composition of caramel. Journal of Agricultural and Food Chemistry, 60(12), 3266-3274. PMid:22375847. http://dx.doi.org/10.1021/jf204807z

Ibáñez, F., Loygorri, S., Ordóñez, A., \& Torre, P. (1998). Evaluación instrumental y sensorial de la textura en quesos de oveja con Denominación de Origen. Alimentaria, 292, 49-53.

Labuza, T., McNally, L., Gallagher, D., Hawkes, J., \& Hurtado, F. (1972). Stability of intermediate moisture foods. 1. Lipid oxidation. Journal of Food Science, 37(1), 154-159. http://dx.doi.org/10.1111/j.1365-2621.1972.tb03408.x

Lim, J. (2011). Hedonic scaling: A review of methods and theory. Food Quality and Preference, 22(8), 733-747. http://dx.doi.org/10.1016/j.foodqual.2011.05.008

Lorenzo, G., Ranalli, N., Andrés, S. C., Zaritzky, N. E., \& Califano, A. N. (2020). Textural characteristics and viscoelastic behavior of traditional Argentinian foods. In K. Nishinari (Ed.), Textural characteristics of world foods (pp 89-106). Nueva Jersey: John Wiley \& Sons. http://dx.doi.org/10.1002/9781119430902.ch7.

Lubbers, S., \& Guichard, E. (2003). The effects of sugars and pectin on flavour release from a fruit pastille model system. Food Chemistry, 81(2), 269-273. http://dx.doi.org/10.1016/S0308-8146(02)00422-3

Marfil, P. H., Anhê, A. C., \& Telis, V. R. (2012). Texture and microstructure of gelatin/corn starch-based gummy confections. Food Biophysics, 7(3), 236-243. http://dx.doi.org/10.1007/s11483-012-9262-3

Martínez, O. (2012). Report spanish confectionary association. Madrid: Produlce.

Monroy, Y., Rivero, S., \& García, M. A. (2017). Functional jelly beans based on hydrocolloids and citrus cremogenates. Journal of Multidisciplinary Engineering Science and Technology, 4(10), 8359-8369.

Pathare, P. B., Opara, U. L., \& Al-Said, F. A. J. (2013). Colour measurement and analysis in fresh and processed foods: A review. Food and Bioprocess Technology, 6(1), 36-60. http://dx.doi.org/10.1007/s11947-012-0867-9

Penci, M. C., \& Marín, M. A. (2016). Dulce de leche: Technology, quality, and consumer aspects of the traditional milk caramel of South America. In K. Kristbergsson \& J. Oliveira (Eds.), Traditional foods: General and consumer aspects (pp. 123-136). Boston: Springer http://dx.doi.org/10.1007/978-1-4899-7648-2_9.

Pittia, P., \& Antonello, P. (2016). Safety by control of water activity: Drying, smoking, and salt or sugar addition. In O. MartínBelloso, L. Keener, S. Astley, S. Braun, H. McMahon \& H. Lelieveld (Eds.), Regulating safety of traditional and ethnic foods (Chap. 2, pp. 7-28). San Diego: Academic Press. http://dx.doi.org/10.1016/B978-0-12-800605-4.00002-5. 
Impact of processing conditions and gelling agent on physical and sensorial properties of pecan oil-dulce de leche gummy candies

Ranalli, N. et al.

Ranalli, N., Andrés, S. C., \& Califano, A. N. (2017). Dulce de leche-like product enriched with emulsified pecan oil: assessment of physicochemical characteristics, quality attributes, and shelf-life. European Journal of Lipid Science and Technology, 119(7), 1600377. http://dx.doi.org/10.1002/ejlt.201600377

Tomassone, M. A., Sosa, C. A., Vergara, L. E., Llugdar Ojeda, M. C., \& Sgroppo, S. C. (2012). Jellies de batata en envases de polipropileno. In II Jornadas de Investigación en Ingeniería del NEA y Países Limítrofes. Chaco, Argentina: Universidad Tecnológica Nacional. Facultad Regional Resistencia.

Vilela, A., Sobreira, C., Abraão, A. S., Lemos, A. M., \& Nunes, F. M. (2016). Texture quality of candied fruits as influenced by osmotic dehydration agents. Journal of Texture Studies, 47(3), 239-252. http://dx.doi.org/10.1111/jtxs.12177

Funding: Consejo Nacional de Investigaciones Científicas y Técnicas (CONICET) (PIP 0546), Agencia Nacional de Promoción

Científica y Tecnológica (PICT 2015-0344) and Universidad Nacional de La Plata (X728).

Received: Aug. 14, 2019; Accepted: July 17, 2020 